For the Journal of the Frabklin Institute.

Particulars of the Steam Ferry Boats Marion and Gen. Warren.

Hulls built by Rosevelt \& Joyce. Machinery by Novelty Iron Works, New York. Intended service, New York to Brooklyn.

HoLL-

Length on deck, from fore part of stem to after part of stern post, above the spar deck,

Breadth of beam at midship section, 142 foet 6 inches.

Floor timlers, at throat-molded, 1 33 "

Frames-apart at centres, 24 ins.

Deptli of hold to spar deck, .

length of engine and boiler space,

Draft of water at load line, .

Draft of water at helow pressure and revolutions, .

Aren of immersed section at this draft,

T'onnage, custom house,

170 sq. ft.

Exaive.-Vertical beam.

Diameter of cylinder, Length of stroke, .

Maximum pressure of steam in pounds, . 25.

Cut-ot, at . . .

Maximum revolutions per minute, $\quad$. 28 ,

Weight of engines and wheels in pounds, $\quad 63,700$.

BorLEB-One-Cylinder, with drop return lues.

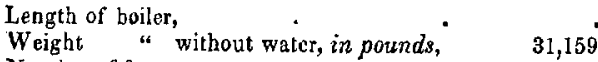

Number of furnaces, . . 2

Breadth " . , ,

Length of grate bars,
Number of flues,

Internal diameter of flues, $\quad 14$ of 14 ins, 2 of 24 ins.

Length of flues, $\left\{\begin{array}{l}\text { upper and lower, } \\ \text { centre, }\end{array}\right.$

Heating surface (fire and fiue), . 1198 sq. ft.

Diameter of smoke pipe, from top of boiler,

Description of coal,

Draft,

12 "4 "

59 "

6 “"

4 ، 6 "

aDDLE Whuels. -

Diameter,

Length of blades,

Depth

Number

.

Bituminous.

Natural.

25 feet.

3 " 10 inches.

6 " 10 "

13 " 5 "

11 “ 39 "

3 " 4 "

40 “
18 feet 6 inches. 8 "s
24 "
C. H. H.

\title{
Straw ILatting.
}

The Abbe Moigno notices in the Cosmos the introduction of a new article, which is a tissue of straw, made of indefinite length, and of any breadth not greater than one metre, $\left(\mathcal{I}_{\mathrm{I}^{1} \cdot \mathrm{I}}\right.$ yards.) It is made by uniting plaits of the straw by thread of preserved hemp or galvanized on tin wires. The fabric is made in a loom, and at the rate of $100 \mathrm{sq}$. yards per day by a single skilled workman. These mattings are extensively used to protect the vineyards and gardens, and experience seems to show that they form a very valuable improvement.

Co8mos, 1st July, 1858, p. 8. 